\title{
AYAT-AYAT AL-QUR'AN TENTANG KURIKULUM
}

\author{
Maulida \\ Intitut Agama Islam Negeri Takengon \\ maulidaamin03@gmail.com
}

\begin{abstract}
Abstrak
Salah satu upaya manusia dalam membentuk Muslim sebagai insan kamil yakni dengan cara menciptakan situasi berinteraksi edukatif secara kondusif dalam pendidikan Islam. Terwujudnya tujuan pendidikan Islam, salah satunya memerlukan sebuah kurikulum. Kurikulum merupakan seperangkat pengaturan dan rencana terkait bahan, isi pengajaran yang diajarkan kepada peserta didik, dan cara pelajaran yang dipakai sebagai pedoman menyelenggarakan satuan pendidikan dalam terwujudnya tujuan pendidikan terutama pendidikan Islam. Komponen kurikulum meliputi tujuan, bahan ajar, metode mengajar, dan penilaian. Kurikulum pendidikan Islam mesti mengacu pada Al-Qur'an dan hadis sebagai dasarnya. Al-Qur'an berisikan ayat-ayat yang memuat tentang kurikulum, yaitu berkaitan tentang bahan, isi yang diberikan untuk peserta didik di lembaga pendidikan, seperti bahan atau materi pendidikan tauhid, ibadah, akhlak, kesehatan, sosial, keterampilan, dan estetika. Dengan demikian, materi tersebut akan mewujudkan peserta didik yang beriman, berakhlak mulia dan berilmu serta terwujudnya peradaban manusia Muslim yang berkualitas.
\end{abstract}

Kata kunci: Al-Qur'an, Kurikulum.

\begin{abstract}
One of the human efforts in shaping Muslims as human beings is by creating a situation of conducive educational interaction in Islamic education. One of the goals of Islamic education is the need for a curriculum. The curriculum is a set of arrangements and plans related to materials, the content of teaching taught to students, and the learning methods used as guidelines for organizing educational units in the realization of educational goals, especially Islamic education. The curriculum components include objectives, teaching materials, teaching methods, and assessment. The Islamic education curriculum must refer to the Qur'an and hadith as its basis. The Qur'an contains verses or the Word of Allah SWT that contains the curriculum, which is related to materials, the content provided to students in educational institutions, such as monotheism educational, worship, morals, health, social skills, and aesthetics. Thus, students who have faith, noble character and knowledge will be realized as well as the realization of quality Muslim human civilization.
\end{abstract}

Keywords: Al-Qur'an, Curriculum. 


\section{PENDAHULUAN}

Salah satu upaya manusia dalam membentuk Muslim sejati sebagai insan paripurna yakni dengan cara menciptakan situasi berinteraksi edukatif secara kondusif dalam pendidikan Islam secara fungsionalnya (Rizal, Samsul, 2005, p. 55). Dalam konteks inilah muncul makna kurikulum. Hadirnya kehidupan yang lebih baik merupakan kebutuhan manusia yang tidak terelakkan, salah satu cara menggapainya yakni dengan menyusun kurikulum. Kurikulum merupakan seperangkat pengaturan dan rencana terkait bahan, isi pengajaran yang diajarkan kepada peserta didik, dan cara pelajaran yang dipakai sebagai pedoman menyelenggarakan satuan pendidikan dalam terwujudnya tujuan pendidikan. Masing-masing jenjang pendidikan dalam menyelenggarakan pendidikan harus mempertimbangkan kesesuaian bahan, isi mata pelajaran dengan kemampuan, keadaannya dalam menyusun kurikulum(Suteja, 2012, p. 119).

Dalam menetapkan tujuan pendidikan, diperlukan alat dalam mencapainya yakni kurikulum yang disebutkan oleh para ahli dalam pendidikan Islam. Fungsi kurikulum dapat sebagai bantuan bagi pengenalan dan pengembangan potensi peserta didik untuk menjadi lebih baik. Pengajaran dan pendidikan akan berhasil jika dalam kurikulumnya termuat kegiatan yang memberi dorongan untuk terwujudnya situasi yang efektif dan efesien dalam tercapainya tujuan untuk membina kepribadian peserta didik, baik dalam aspek afektif, kognitif, dan psikomotorik. Peserta didik harus melalui tahapan-tahapan dalam pengembangan aspek kepribadiannya baik hati, akal, perasaan, intelektual, fisik jasmani (keterampilan) dan kemauannya yang tercantum dalam kurikulum.

Menjabarkan serangkaian ilmu pengetahuan yang diberikan kepada peserta didik, dan kegiatan kependidikan yang diperlukan dan berpengaruh bagi peserta didik untuk mewujudkan tujuan pendidikan Islam dapat disebut juga sebagai kurikulum pendidikan Islam. Dengan demikian, kurikulum merupakan seperangkan materi, isi pelajaran yang mesti tercantum dalam suatu pendidikan untuk menjadikannya bahan pengajaran yang diajarkan kepada peserta didik.

\section{METODE PENELITIAN}

Penelitian ini menggunakan metode telaah pustaka terkait tentang kurikulum. Di sini penulis mencoba membahas ayat-ayat Al-Qur'an tentang kurikulum yang terfokus pada komponen isi atau materi pelajaran yang dapat disampaikan kepada peserta didik dalam proses pembelajaran. Dalam menyusun kurikulum sebagai bentuk untuk mewujudkan tujuan pendidikan Islam, hal yang paling perlu diperhatikan yakni perkembangan teknologi dan Iptek, tahapan perkembangan dan pertumbuhan peserta didik menyesuaikan dengan lingkungannya, dan kebutuhan akan terwujudnya peradaban manusia Muslim yang berkualitas.

Ali Al-Jumbulati berpendapat bahwa isi dari kurikulum pendidikan Islam itu menyesuaikan dengan situasi agama Islam yang berkembang, karena lingkungan dan negara Muslim yang berbeda. Tapi, meskipun demikian, Al-Qur'an menjadi sumber dari ilmu umum dan ilmu agama yang menjadi kesepakatan umat Muslim dalam dunia 
pendidikan sebagai pedoman umat Islam dan rujukan bagi keilmuan yang lain (Jumbulati, 1994, p. 58).

Satu diantara beberapa komponen sebagai penentu sistem pendidikan yakni kurikulum, karena dalam mewujudkan tujuan pendidikan salah satu alatnya yaitu kurikulum. Dan juga kurikulum ini menjadi pedoman bagi tingkat dan jenis pendidikan. Pendapat M. Arifin, bahwa salah satu faktor penting terwujudnya proses mengajar dan belajar di satuan pendidikan Islam yaitu kurikulum. Kurikulum itu ditetapkan dalam hal pengetahuan, pemahaman, penghayatan dan pengalaman peserta didik, dan mencakup apa-apa yang diberikan dan diajarkan kepada peserta didik, semuanya itu terurai di dalamnya(Arifin, 2000, p. 85).

Artikel ini akan membahas tentang pengertian kurikulum menurut beberapa ahli, komponen kurikulum, dan ayat-ayat Al-Qur'an tentang kurikulum. Kurikulum di sini mencakup isi, materi atau bahan yang disampaikan kepada peserta didik dalam sebuah kurikulum pendidikan Islam. Penulis memberikan contoh ayat Al-Qur'an yang berkenaan dengan materi pendidikan tauhid/aqidah, materi pendidikan ibadah, materi pendidikan akhlak, materi pendidikan kesehatan, materi pendidikan sosial, materi pendidikan keterampilan dan materi pendidikan estetika.

\section{HASIL DAN PEMBAHASAN}

\section{Pengertian Kurikulum}

Kurikulum, secara etimologis, asalnya dari bahasa Yunani, curir yang berarti pelari; dan curere berarti jarak yang mesti ditempuh oleh pelari. Awalnya, dalam dunia olah raga istilah ini digunakan. Kurikulum juga dimaknai sebagai suatu lingkaran proses mengajar dan belajar dimana guru dan murid ada di dalamnya (circle of instruction) (Nizar, 2002, p. 56). Kurikulum disebut dengan manhaj al-dirasat dalam Bahasa Arab yang artinya jalan yang terang benderang dilewati manusia dalam segala aspek kehidupan. Manhaj sebagai jalan yang terang menuju pengembangan sikap, pengetahuan, keterampilan yang dilalui oleh pendidik dan peserta didik(Omar Muhammad Al-Toumy Al-Syaibany, 1979, p. 478).

Menurut Crow \& Crow, rencana dalam mengajar yang tersusun sistematis dan isinya merupakan sejumlah bahan pelajaran untuk keperluan peserta didik sebagai persyaratan dalam penyelesaian program kegiatan tertentu merupakan kurikulum (Crow, 1990, p. 199). Ramayulis menyatakan bahwa isi, program studi, kegiatan terencana, reproduksi kebudayaan (kultural), hasil pembelajaran, produksi, dan pengalaman belajar merupakan kategori dari kurikulum(Ramayulis, 2002, p. 127).

Hery Noer Ali menyatakan bahwa pedoman teknis untuk rencana pembelajaran, isi yang berurutan, lingkup dan proses pendidikan dikatan sebagai kurikulum juga(H. N. Ali, 1999, p. 161). Oemar Hamalik berpendapat, kurikulum merupakan seperangkat pengaturan dan rencana terkait bahan, isi, dan cara pelajaran yang dipakai sebagai pedoman menyelenggarakan satuan pendidikan dalam terwujudnya tujuan pendidikan 
(Hamalik, 1995, pp. 16-19). Pendapatnya ini hampir sama dengan makna kurikulum yang ada di Undang-undang Sisdiknas nomor 20 tahun 2003.

Jadi, dalam rangka terciptanya tujuan pendidikan Islam sesuai dengan harapan, mesti ada kurikulum pendidikan Islam yang merupakan rangkaian ilmu yang diajar dan diberikan pada generasi bangsa yakni peserta didik. Dengan kata lain kurikulum sebagai isi, bahan pelajaran pada satuan pendidikan, materi pengajaran yang diajarkan kepada peserta didik. Kurikulum bermakna sebagai suatu lingkaran proses mengajar dan belajar dimana guru dan siswa ada di dalamnya. Kurikulum memiliki cakupan yang luas sekali, oleh karenanya harus dikelola dengan baik.

\section{Komponen-Komponen Kurikulum}

Tyler mengemukakan ada empat pertanyaan dasar yang perlu ada dalam membuat kurikulum dan rencana pengajaran, yaitu:

1. Tujuan pendidikan seperti apa yang ingin diraih oleh sekolah?

2. Pengalaman pendidikan seperti apa yang bisa disiapkan untuk mewujudkan tujuan pendidikan tersebut?

3. Bagaimana pengalaman pendidikan itu bisa dikendalikan atau dilaksanakan dengan baik supaya tujuan tercapai?

4. Bagaimana cara menentukan apakah tujuan-tujuan itu tercapai? (Tyler, 2013, p. 1).

Dari keempat pertanyaan itu dapat disimpulkan bahwa dalam kurikulum harus ada tujuan yang ingin diraih, bahan/isi pelajaran, metode pengajaran, dan penilaian (evaluation). Inilah yang dikatakan komponen kurikulum yang mesti ada di sebuah kurikulum dan saling berkaitan satu dengan yang lainnya. Menurut Nana Saodih komponen-komponen kurikulum terdiri dari tujuan yang ingin diwujudkan, isi/bahan yang akan diajarkan, metode yang digunakan dalam pengajaran, media pengajaran, penilaian pengajaran, dan penyempurnaan dari pengajarannya (Sukmadinata, 2002, pp. 103-112).

Hasan Langulung berpendapat bahwa empat aspek utama yang mesti ada dalam kurikulum yakni: a) Tujuan pendidikan apa yang diharapkan dan digapai oleh satuan pendidikan itu; b) Data-data, pengetahuan, kegiatan, dan pengalaman-pengalaman; c) Metode seorang pendidik dalam pengajaran dan memotivasi peserta didik untuk meningkatkan pelajarannya dan mengarahkan mereka sesuai kurikulum yang ada; d) Penggunaan penilaian sebagai alat ukur, menguji kurikulum dan hasil dari pelaksanaan pendidikan yang termuat dalam kurikulum (Langulung, 1987, p. 303). Jadi, secara umum komponen-komponen kurikulum tersebut terdiri dari tujuan kurikulum yang dicitacitakan, materi yang disampaikan, metode yang digunakan, dan evaluasi yang dilakukan.

\section{Ayat-Ayat Al-Qur'an Tentang Kurikulum}

Pendidikan keimanan/tauhid, berakhlak mulia, intelektual, fisik, sosial, seksual, dan psikis merupakan orientasi dari pendidikan Islam secara kurikulumnya (Ulwan, n.d.). Kemampuan dalam memfilter isi/materi/bahan pelajaran sangat dibutuhkan terutama 
pada proses pembelajaran pendidikan Islam untuk melengkapi semua aspek kurikulumnya. Menurut Kusmin, di buku Hasan Asari, menyebutkan bahwa muatan kurikulum dalam membina keperibadian Muslim, yakni; (1) materi tauhid/aqidah, (2) materi ibadah, (3) materi akhlak, dan masih banyak yang lainnya (Asari, 2020, p. 54).

Ayat-ayat Al-Qur'an tentang kurikulum ini terkait isi atau materi atau muatan kurikulum yang harus disampaikan pada peserta didik melalui proses belajar mengajar untuk mewujudkan tujuan pendidikan terutama pendidikan Islam sesuai dengan apa yang diharapkan. Banyak ayat-ayat Al-Qur'an yang berisi tentang kurikulum pendidikan Islam. Tulisan ini hanya menjelaskan beberapa ayat tentang kurikulum. Muatan kurikulum yang ada dalam ayat-ayat Al-Qur'an tersebut seperti materi pendidikan tauhid/aqidah yang ada dalam surah Al Baqarah ayat 133, materi pendidikan ibadah salah satunya ada dalam surah An-Nuur ayat 55-57, materi pendidikan akhlak terdapat dalam surah Al Imran ayat 159, materi pendidikan kesehatan termuat dalam surah Yunus ayat 57, materi pendidikan sosial salah satunya pada surah al-Hujurat ayat 10 , materi pendidikan keterampilan termuat pada surah Al-An'am ayat 135, dan materi pendidikan estetika terdapat diantaranya dalam surah al-A'raf ayat 31.

\section{Pendidikan Tauhid/Aqidah}

Hal paling utama mesti diajar dan diberikan pada anak didik dalam kurikulum di lembaga pendidikan yaitu materi pendidikan tauhid/aqidah. Mengapa demikian, karena persoalan tauhid/aqidah yang begitu banyak, maka penting ditanamkan di hati dan jiwa peserta didik. Pewarisan persoalan tauhid atau aqidah kepada generasi Muslim penerus peradaban penting dan mesti dilakukan. Adanya aqidah/tauhid maka nilai-nilai Islam berakar kuat di bumi ini, dan keberkahan selalu dilimpahkan Allah SWT. Oleh karenanya, mesti diingatkan pada generasi penerus peradaban Islam untuk selalu istiqomah memperkuat aqidah, yang mana disebutkan dalam Al-Quran surat Al Baqarah/2 ayat 133 sebagai berikut:

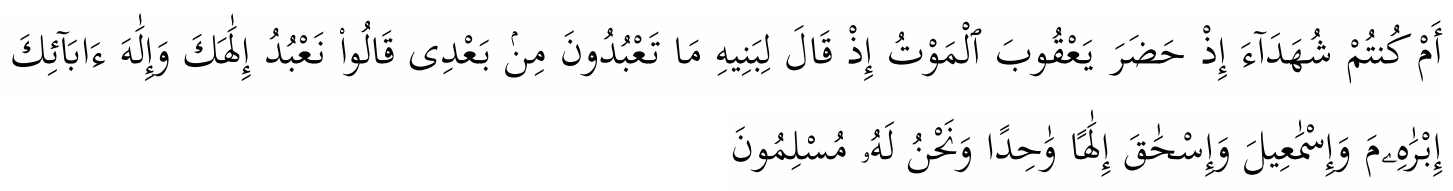

Artinya: Adakah kamu hadir ketika Ya'qub kedatangan (tanda-tanda) maut, ketika ia berkata kepada anak-anaknya: "Apa yang kamu sembah sepeninggalku?" mereka menjawab: "Kami akan menyembah Tuhanmu dan Tuhan nenek moyangmu, Ibrahim, Ismail dan Ishaq, (yaitu) Tuhan yang Maha Esa dan Kami hanya tunduk patuh kepada-Nya".

Arti ayat di atas menjelaskan bahwa ketika Nabi Ya'qub kedatangan sakaratul maut dan bertanya kepada putranya terkait apa yang disembah buah hatinya itu setelah Ya'qub tidak ada. Allah SWT menggerakkan bertanya tentang mengapa mereka hadir, 
bukan malah menanyakan terkait muatan pesan di kitab suci mereka? Ajaran Injil dan Taurat tidak termuat perintah untuk menyekutukan Allah SWT. Oleh karenanya tidak boleh menyekutukan Allah SWT dan harus meng Esakannya. Saat menghadapi sakaratul maut, disitulah terakhir kehidupan di dunia ini. Semua wasiat penting mesti disampaikan kepada ahli waris pada saat perpisahan dan setelah itu tidak akan ada lagi kesempatan. Selanjutnya, pada ayat di atas juga dijelaskan bahwa wasiat tersebut bentuknya sangat meyakinkan sekali. Ya'qub bertanya kepada mereka, dan dijawablah oleh mereka, jadi, yang merupakan wasiat Ya'qub yakni jawaban mereka tentang melaksanakan perintah Allah SWT dan tidak menyekutukan-Nya (Jumbulati, 1994, p. 395).

Jadi, materi pendidikan tauhid/aqidah yang mesti termuat dalam kurikulum pendidikan Islam diantaranya yakni memperkuat aqidah dengan cara mengingat kematian, berwasiat penting sebelum meninggal, taat dan patuh terhadap perintah Allah SWT dan menjauhi larangan-Nya.

\section{Pendidikan Ibadah}

Dalam kurikulum pendidikan Islam, point kedua yang mesti dibina pada peserta didik yakni pendidikan ibadah. Materi pendidikan ibadah seperti shalat, zakat, membaca Al-Qur'an, puasa, berhaji dan lain-lain. Sebagaimana dalam surah An-Nuur/24:55-57, yang berbunyi:

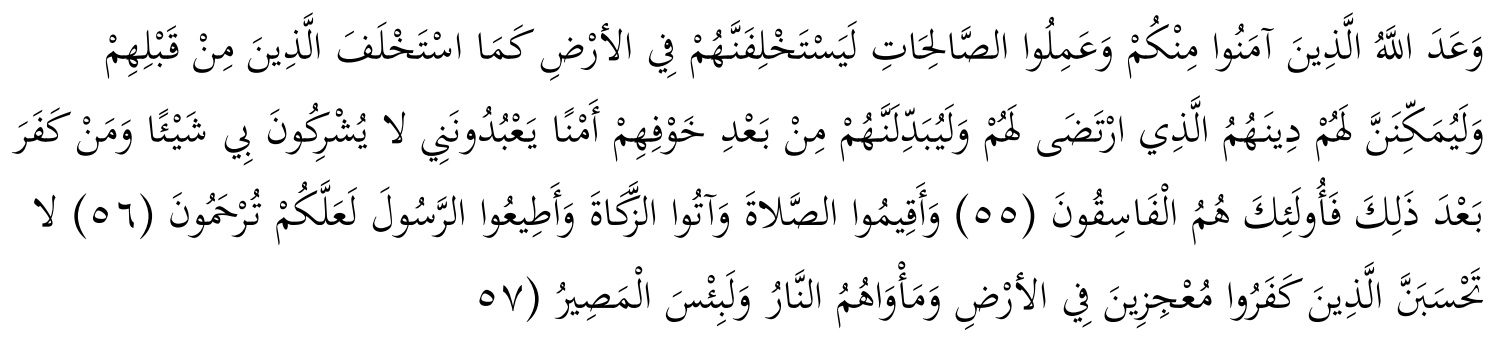

Artinya: Allah SWT telah berjanji dengan mereka yang telah beriman dan mengerjakan amal saleh di antara kamu, akan mewariskan bumi kepadanya dan menjadikan mereka sebagai khalifah sebagaimana orang sebelummu. Allah SWT juga akan meneguhkan agama Islam yang telah diridhai-Nya untuk mereka dan menukarkan ketakutan yang dirasakan dengan keamanan. Mereka menyembah Aku, tidak mempersekutukan sesuatu dengan Aku. Barangsiapa yang mengingkari nikmat-nikmat itu sesudah diberi janji yang demikian, maka merekalah orang-orang yang sangat fasik. Dan Dirikanlah Shalat, tunaikanlah zakat, dan taatilah Rasul. Mudah-Mudahan kamu memperoleh rahmat. Janganlah kamu menyangka bahwa orang-orang kafir itu dapat melemahkan Allah SWT di bumi dan tempat kembali mereka adalah neraka. Itulah sejahatjahat tempat kembali.

Allah SWT menjanjikan kepada para mukmin menjadi khalifah di bumi, bagi yang mau melakukan kebaikan dalam beramal. Keimanan dan beramal saleh sebagai syarat dalam memegang tampuk pemerintahan atau berkuasa. Terpenuhinya syarat 
tersebut, maka umat Islam dapat menjadi khalifah Allah SWT di bumi ini. Agama Islam merupakan agama yang paling Allah SWT ridhai. Islam yakni agama yang kuat dan kukuh dijadikan oleh Allah SWT, dan orang-orang yang berjihad dan berjuang di jalanNya dengan harta bendanya akan menjadi orang hebat dan besar (khalifah), karena mereka hanya mencari keridhaan dan Allah SWT pun ridha kepada mereka. Keadaan menakutkan yang dirasakan oleh mereka, akan diganti dengan rasa keamanan mendalam oleh Allah SWT.

Mendirikan shalat sebagai tonggak utama agama Islam dan mengeluarkan zakat dapat mencegah dari kekejian dan hal yang buruk, dapat membawa keutamaan dan keberkahan dalam hidup. Ini semua merupakan pondasi utama dalam beramal saleh. Shalat itu untuk mewujudkan kebaikan masyarakat dan kebaikan diri pribadi. Begitu juga dengan kewajiban berzakat untuk mewujudkan penguatan hubungan diantara satu orang dengan orang lain dan kebaikan dalam bermasyarakat. Kewajiban berzakat selalu disandingkan dengan perintah mendirikan shalat di dalam ayat Al-Qur'an. Menjauhi larangan Allah SWT dan melaksanakan perintah-Nya, serta mentaati Rasul SAW, akan membuat seseorang itu mendapatkan rahmat Allah SWT.

Orang-orang kafir dapat musnah seketika, jika Allah SWT menghendakinya, karena Allah SWT yang menguasai segalanya. Hidup mereka akan disempitkan-Nya di dunia dan ditempatkan di neraka Jahannam di akhirat kelak sebagai tempat yang paling buruk. Orang-orang mukmin yang taat beribadah kepada Allah SWT, akan dilimpahkan kepada mereka ketentraman, keamanan yang berlimpah, sehingga dengan ketentraman dan keamanan itu mereka dapat melaksanakan ibadah dan menghambakan diri kepadaNya. Bagi orang-orang yang ingkar terhadap kenikmatan yang diberikan Allah SWT, merekalah orang yang ingkar dan melakukan penyelewengan dari kebenaran jalan yang ditunjukkan oleh Allah SWT. Dengan demikian, mendirikan shalat, menunaikan zakat dan mentaati Rasul SAW merupakan wujud rasa syukur kepada kenikmatan yang diberikan oleh Allah SWT dalam menjalankan perintah-Nya, dan rahmat-Nya pun dapat diperoleh(Ash-Shiddieqy, 2000, pp. 2843-2846).

Orang tua Muslim, disuruh oleh Rasul Muhammad SAW untuk melakukan pendidikan, pembinaan, dan pembiasaan mengerjakan shalat lima waktu kepada buah hati atau putra putrinya apabila mereka sudah berumur tujuh tahun. Sabda beliau yang arinya: Dari Jaddah berkata Rasulullah Saw; "Ajarilah (didiklah) anak-anakmu dengan shalat, jika telah berusia tujuh tahun dan pukullah (jika meninggalkan salat) dia jika telah berusia sepuluh tahun". Usia tujuh tahun anak-anak itu merupakan waktu yang tepat dalam memberikan pendidikan shalat. Sebenarnya pembiasaannya dimulai dari usia anak sejak dini. Jika anak-anak meninggalkan shalatnya setelah mereka berumur sepuluh tahun, maka orang tuanya dapat memberikan nasihat dan peringatan dengan cara memukulnya. Pukulan ini dilakukan dengan cara lembut dan tidak keras serta kasar yang dapat melukai dan menyiksa anak serta melampaui kasih sayang. Pukulan sebagai tanda mengingatkan agar anak melaksanakan shalat seperti dianjurkan oleh Rasul SAW dengan menunjukkan kasih sayang. 


\section{Pendidikan Akhlak}

Pendidikan akhlak juga sangat penting diajarkan kepada peserta didik dalam kurikulum pendidikan Islam. Materi pendidikan akhlak yakni akhlak kepada Allah SWT, akhlak kepada Rasulullah SAW, akhlak kepada orang tua, akhlak kepada sesama manusia, akhlak kepada tetangga, dan akhlak kepada lingkungan dan makhluk Allah SWT yang lainnya. Akhlak terhadap orang tua contohnya berkata lemah lembut kepada kedua orang tua. Hal ini disebutkan dalam firman Allah SWT dalam surah Al-Isra' ayat 23.

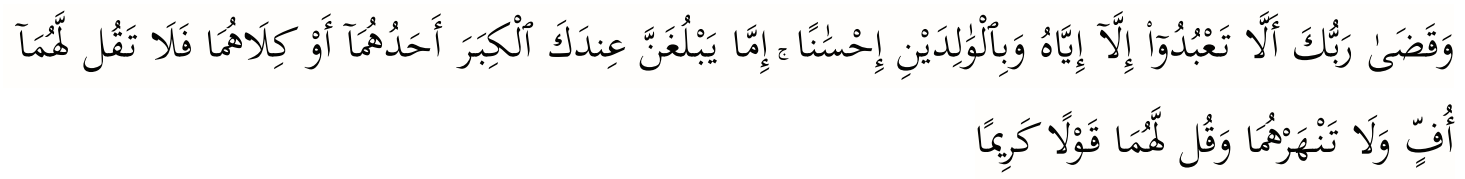

Artinya: Dan Tuhanmu telah memerintahkan agar kamu jangan menyembah selain Dia dan hendaklah berbuat baik kepada ibu bapak. Jika salah seorang di antara keduanya atau kedua-duanya sampai berusia lanjut dalam pemeliharaanmu, maka sekali-kali janganlah engkau mengatakan kepada keduanya perkataan "ah" dan janganlah engkau membentak keduanya, dan ucapkanlah kepada keduanya perkataan yang baik. (Q.S. Al-Isra' (17): 23) .

Allah SWT juga berfirman dalam surah Al Imran/3 ayat 159 yang memiliki arti yakni: Maka disebabkan rahmat dari Allah SWT lah, engkau berlaku lemah lembut terhadap mereka. Sekiranya engkau berlaku keras lagi berhati kasar, tentulah mereka menjauhkan diri dari sekelilingmu. Karena itu maafkanlah mereka, mohonkanlah ampunan bagi mereka, dan bermusyawarahlah dengan mereka dalam urusan (itu). Kemudian apabila engkau telah membulatkan tekad, maka bertawakkallah kepada Allah swt. Sesungguhnya Allah swt menyukai orang-orang yang bertawakkal kepada-Nya.

Pada dasarnya Allah SWT membimbing dan menuntun Nabi Muhammad SAW di ayat ini. Sikap Nabi SAW yang lemah lembut terhadap kaum Muslimin yang mana pernah melanggar dan berbuat salah dalam peperangan Uhud. Rasul SAW membuktikan dengan kelembutannya, beliau melaksanakan musyawarah bersama mereka sebelum terjadi peperangan. Penerimaan usulan juga beliau lakukan, meskipun kurang suka dengah hal tersebut, tapi beliau hanya berlaku baik dan halus lembut, jika para pemanah pergi dari markas, beliau tidak menyalahkannya dan tidak kasar kepada mereka. Ini semua atas rahmat Allah SWT yang begitu besarnya. Musyawarah disini maksudnya yaitu kesepakatan pada permasalahan peperangan dan permasalahan keduniaan, tidak terkait dengan permasalahan agama atau syariat.

Allah SWT sendiri melalui surah Al Imran ayat 159 membuktikan pembentukan dan pendidikan keperibadian Rasul Muhammad SAW. Pembentukan keperibadiannya, tidak hanya sekedar ilmu pengetahuannya saja yang Allah SWT berikan lewat firmanNya (Al-Qur'an), tetapi juga qalbu Rasul SAW disinari dan menjadikan beliau rahmat untuk keseluruhan alam semesta ini. Rasul Muhammad SAW memiliki akhlak yang 
terbaik, sikapnya tidak kasar atau keras, beliau selalu memberi maaf, dan mau mendengarkan saran dari orang lain.

Langkah-langkah yang dilakukan Nabi yang Allah SWT perintahkan sebelum melaksanakan musyawarah yakni bersikap sopan santun dengan kelembutan hati, tidak memiliki hati yang keras dan tidak berkata kasar kepada orang lain yang ada dalam musyawarah tersebut; Pemberian maaf kepada orang lain yang melakukan kesalahan karena berbeda pendapat dalam musyawarah tersebut; dan keharmonisan hubungan dengan Allah SWT dan memohon ampun kepada-Nya untuk mewujudkan hasil terbaik dari musyawarah itu; serta melaksanakan hasil musyawarah dan menyerahkan semuanya kepada Allah SWT, karena orang-orang yang melakukan penyerahan diri kepada-Nya, sangat Allah SWT sukai (M. Quraish Shihab, 2006, pp. 255-263).

\section{Pendidikan Kesehatan}

Materi tentang pendidikan kesehatan terdapat dalam Al-Qur'an surah Yunus ayat 57.

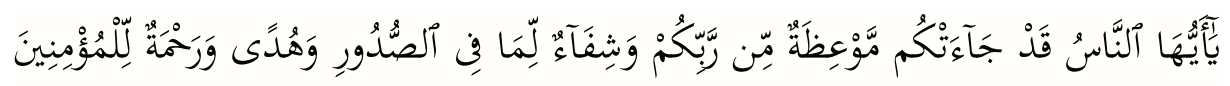

Artinya: Hai manusia, Sesungguhnya telah datang kepadamu pelajaran dari Tuhanmu dan penyembuh bagi penyakit-penyakit (yang berada) dalam dada dan petunjuk serta rahmat bagi orang-orang yang beriman.

Ayat tersebut menjelaskan bahwa Allah SWT telah memberi rahmat dan karuniaNya kepada semua makhluk-Nya berupa kitab suci Al-Qur'an yang disampaikan kepada Rasul SAW dan menjadikan beliau sebagai suri tauladan umat Islam. Al-Qur'an sebagai pelajaran dari Allah SWT berupa rahmat dan petunjuk-Nya, dapat terhindar dari sikap yang keji, munkar, keraguran dan juga sebagai obat dari segala penyakit yang tertanam di hati manusia. Al-Qur'an, menjadikan hati tenang karena rahmat dan hidayah Allah SWT limpahkan kepada manusia yang beriman dan bertakwa kepada-Nya, serta meyakini isi kandungan Al-Qur'an tersebut.

Al-Qur'an surah Al-Israa' ayat 82 juga menyebutkan bahwa Allah SWT menurunkan Al-Qur'an itu sebagai obat atau penawar dan menjadi rahmat bagi orangorang beriman. Sedangkan bagi orang-orang zalim akan mendapatkan kerugian. Dengan demikian, ayat tersebut mengandung materi tentang pengobatan dari penyakit untuk menjaga kesehatan.

\section{Pendidikan Sosial}

Materi tentang pendidikan sosial yakni tentang persaudaraan dan perdamaian, salah satunya ada dalam surah Al-Hujurat ayat 10 berikut ini:

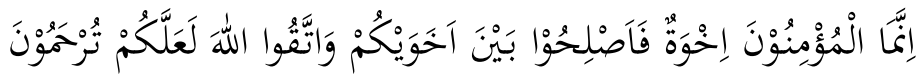


Artinya: Orang-orang beriman itu Sesungguhnya bersaudara, sebab itu damaikanlah (perbaikilah hubungan) antara kedua saudaramu itu dan takutlah terhadap Allah, supaya kamu mendapat rahmat.

Maksud ayat ini yakni yang dikatakan saudara itu ialah orang-orang beriman, mukmin yang seagama (Islam). Jadi jika ada dua orang beriman yang melakukan pertengkaran atau perkelahian, maka damaikanlah mereka, dan selanjutnya akan memperoleh rahmat dari Allah SWT apabila bertakwa kepada-Nya(Al-Mahalli \& al Suyuthi, 1990). Meskipun tidak dari keturunan yang sama, keharusan mendamaikannya dan berdamai adalah karena merupakan saudara seagama dan seiman dalam Islam. Perdamaian itu harus selalu dijaga baik antar kelompok maupun antar individu, jika terjadi perselisihan, maka segera damaikanlah, dan menjaga diri agar terhindar dari bencana akibat pertengkaran tersebut, supaya memperoleh rahmat dari dari Allah SWT berupa persatuan dan kesatuan(M. Quraish Shihab, 2006, pp. 598-599).

Ayat ini dipahami bahwa sebagai saudara kita yakni orang-orang yang memiliki keimanan yang sama yaitu Islam. Tumbuhnya keimanan dalam hati masing-masing akan memperkuat persaudaraan, terhindar dari perselisihan dan permusuhan. Jika perselisihan itu terjadi karena hal lain seperti kesalah pahaman antara saudara Muslim, maka segeralah mencari kebenarannya agar tidak terjadi musibah yang merugikan orang lain(Haji Abdul Malik Abdulkarim Amrullah, 2007, p. 6825). Pengharapan akan ridha Allah SWT merupakan tujuan dari perdamaian dan mendamaikan tersebut, bukan yang lainnya. Jadi, sebagai masyarakat Muslim mesti saling mengingatkan satu dengan yang lainnya melalui kebaikan untuk melaksanakan perintah Allah SWT dan menjauhi kemungkaran, sehingga dengan rasa cinta, perdamaian, kasih sayang, persatuan dan kerjasama maka rahmat persaudaraan ini akan terwujud (Sayyid Quthb, 2004, p. 417).

\section{Pendidikan Keterampilan}

Materi tentang pendidikan keterampilan seperti bekerja keras, berbuat sepenuh kemampuan, dan memiliki kepandaian, termuat dalam surah Al-An'Am ayat 135.

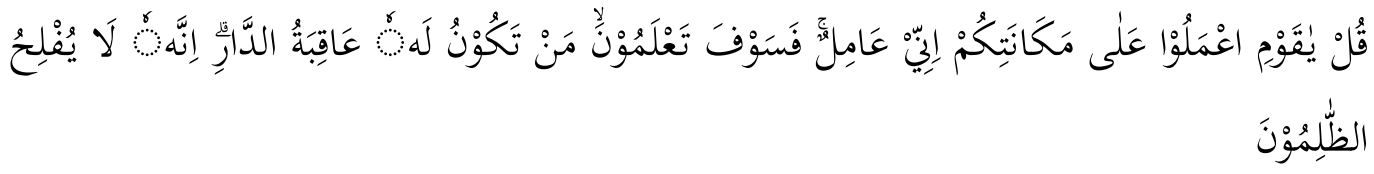

Artinya: Katakanlah: "Hai kaumku, berbuatlah sepenuh kemampuanmu, Sesungguhnya akupun berbuat (pula). Kelak kamu akan mengetahui, siapakah (di antara kita) yang akan memperoleh hasil yang baik di dunia ini. Sesungguhnya orang-orang yang zalim itu tidak akan mendapatkan keberuntungan.

Ayat ini memiliki maksud bahwa seorang Muslim harus berbuat sepenuh kemampuan. Ini merupakan arahan yang di berikan Rasul SAW kepada kaumnya melalui petunjuk Allah SWT untuk melakukan sesuatu sesuai kemampuan yang dimiliki dengan 
sekuat tenaga. Di dunia, Muslim mesti terus mengasah kemampuannya dan tetap berjalan sesuai dengan petunjuk Allah SWT untuk mendapatkan hasil yang terbaik. Orang yang zalim, tidak akan mendapatkan hasil yang maksimal dan tidak beruntung. Keterampilan diartikan sebagai suatu kemampuan atau cekatan dalam menyelesaikan tugas-tugas(A. Ali, 2000, p. 658). Kemampuan (skill), disebut maharah atau miran di bahasa Arabnya, yang artinya kepandaian. Karena kepandaian membuat suatu produk, sering diperoleh setelah seseorang mendapatkan pendidikan atau pelatihan, yang disebut skill yang diartikan sebagai kepandaian.

Pendidikan keterampilan adalah suatu upaya untuk (1) kemampuan fisik: yaitu kemampuan bekerja karena ia sehat jasmani; (2) kemampuan akal (rasio): yaitu kemampuan untuk menggunakan teori-teori sebagai dasar untuk menciptakan suatu produk yang diinginkan; (3) Kemampuan hati (qalbu): yaitu kemampuan untuk menciptakan produk yang bisa dihasilkannya berupa jasa, barang yang memuaskan diri setiap manusia, karena didalamnya ada unsur estetika dan etika yang selalu mengiringinya (Mahyudin, 2018, pp. 75-76).

\section{Pendidikan Estetika}

Materi tentang pendidikan estetika seperti mengenakan pakaian yang indah, cantik dan tidak berlebih-lebihan, terdapat dalam surah Al A'raf ayat 31.

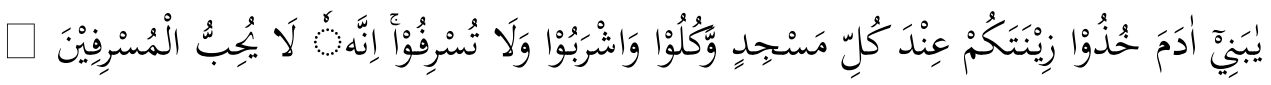

Artinya: Hai anak Adam, pakailah pakaianmu yang indah di Setiap (memasuki) mesjid, makan dan minumlah, dan janganlah berlebih-lebihan. Sesungguhnya Allah tidak menyukai orang-orang yang berlebih-lebihan.

Maksud ayat tersebut yakni Allah SWT memerintahkan kepada semua Muslim berpakaian dengan indah jika hendak masuk ke dalam Mesjid. Perintah ini pada awalnya disampaikan kepada orang-orang yang memiliki kebiasaan ketika bertawaf di Ka'bah, mereka tidak memakai busana. Kaum pria melakukannya pada siang hari, dan di malam hari kaum wanitanya melakukan tawafnya. Dari sinilah sejak Islam hadir, Allah SWT memberi perintah mengenakan pakaian indah-indah yakni dapat menutup aurat kaum Muslim, bahannya juga harus dipilih dari bahan kain terbaik yang bisa dijadikan pakaian untuk menutup aurat. Pakaian indah ini mesti dipakai pada tiap memasuki masjid sesuai perintah Allah SWT. Jadi, berdasarkan ayat ini sunat hukumnya bila berpakaian yang indah dan memakai wangi-wangian jika melakukan shalat, terutama shalat hari raya Islam dan shalat Jum'at. Bersiwak juga sunat hukumnya, karena siwak ini sebagai kesempurnaannya.

Allah SWT juga memerintahkan bahwa makanlah sesukamu dan berpakaianlah sesukamu tetapi jangan berlebih-lebihan dan sombong. Perintah ini disampaikan Allah SWT untuk meminum dan memakan rezeki yang halal-halal bukan haram. Makanan dan 
minuman yang haram jika kita memakannya maka termasuk perbuatan yang sangat berlebihan, dan bisa tergolong ke dalam kategori melampaui batas ketentuan Allah SWT terkait haram dan halal. Allah SWT sangat suka dengan orang-orang yang memiliki sikap menghalalkan sesuatu sesuai dengan yang dihalalkan oleh Allah SWT, dan mengharamkan sesuatu yang sudah diharamkan Allah SWT.

\section{KESIMPULAN}

Al-Qur'an berisikan banyak ayat-ayat tentang komponen pendidikan. Salah satunya ayat-ayat tentang kurikulum. Artikel ini membahas ayat-ayat Al-Qur'an tentang muatan kurikulum berkaitan tentang materi/bahan/isi yang diberikan untuk peserta didik di lembaga pendidikan terutama lembaga pendidikan Islam, seperti materi pendidikan tauhid, materi pendidikan ibadah, materi pendidikan akhlak, materi pendidikan kesehatan, materi pendidikan sosial, materi pendidikan keterampilan, dan materi pendidikan estetika.

Ayat Al-Qur'an tentang materi pendidikan tauhid salah satunya terdapat dalam Q.S. Al Baqarah ayat 133, materi pendidikan ibadah ada dalam Q.S. An-Nuur ayat 5557, materi pendidikan akhlak termuat dalam Q.S. Al Imran ayat 159, materi pendidikan kesehatan yakni Q.S. Yunus ayat 57, materi pendidikan sosial ada pada Q.S. al-Hujurat ayat 10, materi pendidikan keterampilan ada dalam Q.S. Al-An'am ayat 135 dan materi pendidikan estetika terdapat pada Q.S. al-A'raf ayat 31.

Kurikulum yang dilaksanakan dalam lembaga pendidikan Islam mesti mengacu pada Al-Qur'an dan hadis. Peserta didik yang beriman, berakhlak mulia dan berilmu serta terwujudnya peradaban manusia Muslim yang berkualitas merupakan tujuan pendidikan Islam. Oleh karenanya, dalam mencapai tujuan tersebut mesti dibarengi dengan materimateri pada kurikulum yang sesuai dengan ayat-ayat Al-Qur'an. Semua guru hendaknya mengetahui ayat-ayat Al-Qur'an tentang kurikulum. 


\section{DAFTAR PUSTAKA}

Al-Mahalli, I. J., \& al Suyuthi, I. J. (1990). Tafsir Jalalain Berikut Asbabun Nuzul Ayat. Terj. Mahyudin Syaf. Bandung: Sinar Baru.

Ali, A. (2000). Kamus Inggeris Indonesia Arab. Multi Karya Grafika.

Ali, H. N. (1999). Ilmu Pendidikan Islam. Logos.

Arifin, M. (2000). Filsafat Pendidikan Islam. Bumi Aksara.

Asari, H. (2020). Hadis-Hadis Pendidikan sebuah penelusuran akar-akar ilmu pendidikan Islam. Perdana Publishing.

Ash-Shiddieqy, T. M. H. (2000). Tafsir Al-Qur'anul Majid, An-Nuur Jilid 4. Pustaka Rizki Putra.

Crow, C. \&. (1990). Pengantar Ilmu Pendidikan. Rake Sarasin.

Haji Abdul Malik Abdulkarim Amrullah. (2007). Tafsir al-Azhar. Kerjaya Print Pte Ltd. Hamalik, O. (1995). Kurikulum dan Pembelajaran bumi Aksara Jakarta.

Jumbulati, A. Al. (1994). Perbandingan Pendidikan Islam. Rineka Cipta.

Langulung, H. (1987). Azas-azas Pendidikan Islam. Pustaka al-Husna.

M. Quraish Shihab. (2006). Tafsir Al Mishbah: Pesan, Kesan dan Keserasian AlQur'an, Volume 2. Lentera Hati.

Mahyudin. (2018). Tafsir Tarbawi: Kajian Ayat-ayat al-Qur'an dengan Tafsir Pendidikan (Kalam Mulia (ed.)).

Nizar, S. (2002). Filsafat Pendidikan Islam, Pendekatan Historis, Teoritis, dan Praktis. Ciputat Press.

Omar Muhammad Al-Toumy Al-Syaibany. (1979). Falsafah Pendidikan Islam. Bulan Bintang.

Ramayulis, I. P. I. (2002). Jakarta: Kalam Mulia. 1998.

Rizal, Samsul, A.-R. (2005). Filsafat Pendidikan Islam. Ciputat Press.

Sayyid Quthb. (2004). Tafsir Fi Zhilalil Qur'an Di Bawah Naungan Al Qur'an (Surat ash Shaffaat 102-al Hujarat). Gema Insani Press.

Sukmadinata, N. S. (2002). Pengembangan kurikulum teori dan praktek.

Suteja. (2012). Tafsir Tarbawi: Pengantar Tafsir Tarbawi. Pangger.

Tyler, R. W. (2013). Basic principles of curriculum and instruction. University of Chicago press.

Ulwan, A. N. (n.d.). Pendidikan Anak dalam Islam: Studi Atas Pemikiran Ibnu. 